\begin{tabular}{l} 
MIMESIS \\
Universitas \\
Ahmad Dahlan \\
VOL. 3. No. 1, Januari 2022 \\
\hline
\end{tabular}

\title{
WANITA (NYAIE) DALAM NOVEL BUNGA ROOS DARI CIKEMBANG KARYA KWEE TEK HOAY
}

\section{Nur Alifah Septiani}

Sastra Indonesia, Fakultas Sastra, Budaya, dan Komunikasi,_Universitas Ahmad Dahlan, Yogyakarta nur.alifah@idlitera.uad.ac.id

\section{Dedi Pramono}

Sastra Indonesia, Fakultas Sastra, Budaya, dan Komunikasi,_Universitas Ahmad Dahlan, Yogyakarta dedi.pramono@idlitera.uad.ac.id

\section{ARTICLE INFO}

\section{ABSTRACT}

\section{Article history}

Received 10 January 2022

Revised 27 January 2022

Accepted 29 January 2022

\section{Keywords}

Conception of Woman

Concubine

Bunga Roos dari Cikembang
Over 90 years (1870-1960), 800 authors published 3000 Chinese Malay erudite workshops. Bunga Roos from Cikembang is one of the most well-known workshops. The work was written by Kwee Tek Hoay, one of the most prolific authors of his day. Bunga Roos from Cikembang, similar to the previous Chinese Malay literary work, casts an indigenous womanish figure as a Chinese man's "nyaie." The distinction in this tale is that the "nyaie" is elevated to a higher status. She is no longer referred to as a "mistress" (a libido grater), but rather as a lady by her master, even though she has never been married. This distinction is noteworthy and warrants additional investigation. The goal of this research is to locate honorable examples for the female character who becomes the "nyaie" in a detail in this sense, the study theory employed a gender theory, specifically Richard A. Lippa's notions of nature and nurture. This research is the outcome of a library search. The data analysis was done in a descriptive-qualitative manner. Marsiti, like a lady"nyaie" (concubine) of a high-class Chinese, was lauded not only as a woman who satisfies her master's lust because of her beauty, sexiness, and service (nature) but also as a woman in a good social arrangement (nurture). Marsiti is seen as a "partner" who can be relied upon to help the master think through the various challenges that arise in his life as a result of his wimpiness, intelligence, and fidelity. In this case, the location of the woman "nyaie" in Kwee Tek Hoay's Cikembang Bunga Roos appears to be superior to the previous work.

This is an open access article under the $C C-B Y$-SA license.

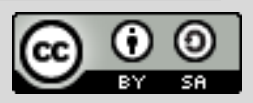

\section{Article history}

Received 10 Januari 2022

Revised 27 Januari 2022

Accepted 29 Januari 2022

Keywords

Konsepsi Wanita

Nyaie

Bunga Roos dari Cikembang
Dalam kurun waktu sekitar 90 tahun $(1870$ - 1960) telah terbit karya sastra Melayu Tionghoa sejumlah 3000-an judul dari 800-an penulis. Salah satu karya yang terkenal adalah Bunga Roos dari Cikembang. Novel tersebut ditulis oleh salah seorang pengarang produktif pada zamannya, bernama Kwee Tek Hoay. Hampir sama dengan karya sastra Melayu Tionghoa yang lahir sebelumnya, Bunga Roos dari Cikembang, menempatkan tokoh wanita pribumi sebagai "nyaie" dari seorang laki-laki tionghoa. Perbedaannya pada novel ini sang "nyaie" ditempatkan dalam posisi yang lebih terhormat, dia tidak lagi ditempatkan sebagai "gundik" (pemuas libido) tetapi telah diakui sebagai istri oleh tuannya, walau tanpa pernikahan resmi. Perbedaan ini cukup menarik untuk ditelaah lebih jauh. Adapun tujuan kajian ini adalah menemukan model-model kehormatan tokoh wanita yang menjadi 'nyai" tersebut secara rinci. Dalam kaitan ini teori kajian yang dipakai menggunakan teori gender, terutama konsep nature dan nurture dari Richard A. Lippa. Kajian ini merupakan hasil penelitian pustaka. Kajian data dilakukan secara deskriptif-kualitatif. Hasil kajian menunjukkan bahwa Marsiti sebagai wanita "nyaie" (gundik) dari seorang Tionghoa berkelas atas tidak hanya ditempatkan sebagai wanita pemuas nafsu biologis dari tuannya karena kecantikannya, keseksiannya dan pelayanannya (secara nature) namun juga diposisikan sebagai wanita dalam konstruksi sosial (secara nurture) yang baik. Marsiti diakui sebagai "isteri" yang mampu dijadikan sebagai kawan berpikir tentang beragam problematika kehidupan tuan yang didampinginya akibat kelembuatannya, kecerdasannya dan kesetiannya. Dalam hal ini, penempatan wanita "nyaie" pada Bunga Roos dari Cikembang karya Kwee Tek Hoay terlihat lebih terhormat dari karya sebelumnya.

This is an open access article under the CC-BY-SA license. 


\section{PENDAHULUAN}

Stereotipe merupakan pelabelan terhadap suatu kelompok tertentu (Fakih, 2012: 16). Wanita dalam masyarakat Indonesia memiliki stereotipe yang berbeda terhadap laki-laki. Stereotipe wanita yang seperti diungkapkan oleh Fakih (2012: 72-76) bahwa dalam kontruksi gender wanita (1) berada pada posisi dimiskinkan secara ekonomi, (2) berada pada posisi subordinasi, (3) mendapat pelabelan negatif, (4) sebagai makhluk yang lemah, dan (5) berada pada ranah domestik. Stereotipe yang dikemukakan oleh Fakih tersebut merupakan sebuah kontruksi sosial yang lekat terhadap wanita. Konstruksi terhadap pelabelan wanita atau lakilaki dikemukakan oleh Lippa bahwa konsepsi tersebut disebut sebagai nurture. Nurture merupakan pembentukan streotipe sifat wanita atau laki-laki karena pola pengasuhan orang tua dan masyarakat (Lippa, 2005: 113-118). Hal itu dapat dikatakan bahwa stereotipe wanita atau laki-laki terbentuk karena kontruksi sosial budaya. Adapun menurut Lippa (2005: 103), dalam Konsep gender terdapat juga istilah nature yang merupakan pembentukan sifat wanita atau laki-laki berdasarkan bawaan kondisi biologisnya. Kedua istilah tersebut memiliki dua pijakan yang berbeda, nurture pada kontruksi sosial sementara nature pada biologis (Lippa, 2005: 84).

Menurut (Meij, 2009: 78-81), wanita memiliki banyak peran dalam masyarakat tetapi dalam kontruksi budaya patriaki yang melekat pada budaya masyarakat Tionghoa posisi wanita berada di bawah laki-laki. Wanita dalam budaya Tionghoa dianggap tidak berguna. Di sisi lain perempuan memiliki beban sebagai penerus dan penjaga tradisi keluarga. Hal ini menunjukkan adanya ambivalensi posisi wanita dalam masyarakat Tionghoa. Gambaran relasi wanita pribumi dengan wanita Tionghoa terlihat pada novel Bunga Roos dari Cikembang karya Kwee Tek Hoay diterbitkan tahun 1927 oleh Drukkerij Hoa Siang In Kok Batavia. Karya ini merupakan pesanan tuan Ong Tjoei Hong untuk dimainkan dalam drama oleh Union Dalia Opera pada tanggal 5 Maret 1927. Hampir dua bulan kemudian novel ini diterbitkan secara berkala dalam mingguan Panorama mulai 20 April 1927. Novel Bunga Roos dari Cikembang terdiri dari 16 (enam belas) bab yang didahului pengantar pengarang dalam subjudul Permulaan Kata. Keenam belas bab tersebut bersubjudul sebagai berikut Awan Item yang Mendatengin; Perpisahan; Jau Di Mata, Jau Di Hati; Rahasia Terbenam; Abis Ujan Dateng Panas; Alamat dari Kesedihan; Folie Circulaire; Puhun Puring Mangkok-Mas; Bunga Roos dari Cikembang; Satu Resia dari Dalam Kubur; Lily Idup Kembali; Patung Idup; Kembang Cente dan Harendong; Keheranannya Kota Betawi; dan Bingkisan dari Marsiti. 
Novel Bunga Roos dari Cikembang disunting kembali oleh Marcus A.S dan Pax Benedanto menjadi kurang lebih 126 halaman setengah folio (dari halaman 298 - 425) dan diterbitkan kembali bersama 6 (enam) judul cerita lainnya dalam judul buku Kesastraan Melayu Tionghoa dan Kebangsaan Indonesia Jilid II oleh Kepustakaan Populer Gramedia pada tahun 2001. Istilah bunga roos (mawar) dari Cikembang merupakan simbol yang dipredikatkan kepada seorang wanita cantik dari Cikembang yang bernama Roosminah. Novel-novel Melayu Tionghoa pada umumnya menggunakan 'nama' salah seorang tokoh utama, tokoh yang dijadikan pusat cerita, sebagai judul, seperti, seperti novel Lo Fen Koei karya Gouw Peng Liang, Cerita Nyai Soemirah dan Oey Se karya Thio Tjin Boen, atau Sie Po Giok karya Tio Ie Soei. Berbeda dengan novel-novel Melayu Tionghoa tersebut novel Bunga Roos dari Cikembang, penceritaan Roosminah sebagai nama tokoh yang dijadikan judul novel diceritakan di bagian akhir cerita (dalam 7 bab terakhir dari 17 bab yang tersaji). Novel tersebut menempatkan empat tokoh wanita, Roosminah (Sang bunga Roos dari Cikembang), Gwat Nio, Lily, dan Marsiti.

Marsiti merupakan tokoh wanita dalam novel Bunga Roos dari Cikembang yang berperan sebagai gundik dalam keluarga Tionghoa. Tokoh Marsiti dan Roosminah sebagai keturunan (peranakan Tionghoa) dengan relasinya terhadap tokoh wanita lain yang merupakan wanita Tionghoa menjadi fokus kajian dalam artikel ini. Kajian terkait gundik/ nyai dilakukan Baay (2017: xiv) yang mengulas dinamika nyai dan pergundikan di Hindia Belanda. Dalam kajiannya mengungkapakan sejarah kemunculan keturunan Indo dan ketidakadilan yang diterima oleh wanita pribumi. Adapun Irenewaty \& Adhi (2016) mengungkapkan perjuangan wanita di masa Kolonial sebagai Nyai. Nyai dalam kajiannya memiliki perananan sebagai mediator budaya Jawa dan Eropa. Dalam masyarakat Tionghoa yang merupakan golongan kedua dalam masyarakat Indonesia (Hindia Belanda) juga mengenal konsep pergundikan/pernyaian seperti yang dikemukakan oleh Sungkowati (2009) bahwa wanita Jawa memiliki kedudukan lebih rendah dari wanita Tionghoa sehingga laki-laki Tionghoa menempatkan perempuan Jawa sebagai gundik. Hal ini sesuai yang diungkapkan oleh Selo Sumardjan dalam Sungkowati (2009) bahwa dalam masyarakat berkembang pemikiran bahwa etnis Tionghoa lebih unggul dari etnis Indonesia asli. Oleh karena itu, kajian terhadap nyaie dalam teks sastra menarik untuk diangkat ke permukaan. Hal ini berkaitan erat dengan sejarah bangsa Indonesia dan untuk melihat sejauh mana posisi wanita pribumi dan wanita Tionghoa dalam dinamika masyarakat Indonesia yang tercermin dalam karya sastra peranakan. Adapun 
novel peranakan berjudul novel Bunga Roos dari Cikembang pernah ditelaah oleh Pramono (2019) dengan judul "Citra Wanita Pribumi dalam Sastra Melayu Tionghoa”. Selain itu, Nugroho dan Purnomo (2017) berjudul "Citra Perempuan dalam Karya sastra Peranakan Tionghoa”. Adapun Hudaa et al. (2021) mengangkat budaya yang terkandung dalam novel Bunga Roos dari Cikembang dan ditemukan bahwa ada tiga budaya yakni Jawa, Sunda, dan Tionghoa dalam novel tersebut.

Berbagai telaah di atas belum menggunakan teori sosial secara spesifik, sedangkan pada kajian ini sudah menggunakan teori nature dan nurture Richard A. Lippa dari buku Gender, Nature, and Nurture. Dengan demikian, kajian yang dilakukan cenderung lebih mendalam daripada kajian-kajian sebelumnya yang masih berkesan impresionistik.

\section{METODE}

Objek material dalam penelitian ini adalah semua struktur novel Bunga Roos dari Cikembang, seperti yang dikemukakan oleh Faruk (2012: 23) objek material dalam penelitian sastra adalah lahan penelitian yakni keseluruhan struktur yang terdapat dalam novel Bunga Roos dari Cikembang . Adapun objek formal oleh Faruk (2012: 23) dikatakan sebagai sudut pandang peneliti dalam melihat lahan penelitian maka objek formal dalam penelitian ini adalah tokoh wanita Pribumi (Nyaie) yang berada dalam keluarga Tionghoa yang terdapat dalam novel Bunga Roos dari Cikembang. Langkah-langkah yang dilakukan dalam penelitian ini sebagai berikut.

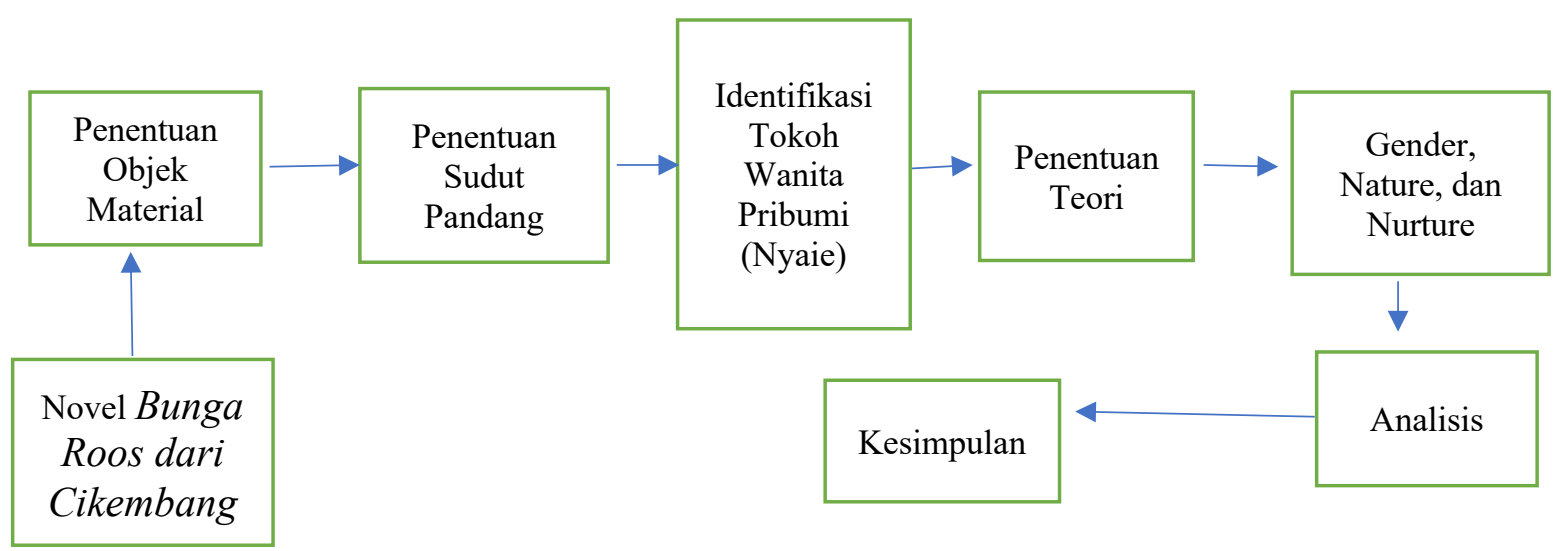

\section{PEMBAHASAN}

\section{Novel Bunga Roos dari Cikembang Karya Kwee Tek Hoay}

Novel Bunga Roos dari Cikembang karya Kwee Tek Hoay merupakan naskah drama yang dipesan oleh tuan Ong Tjoei Hong sebagai naskah yang akan dipentaskan pada awal tahun 
1927 oleh Union Dalia Opera. Sebagai novel Bunga Ross dari Cikembang diterbitkan oleh Drukkerij Hoa Siang In Kok di Batavia pada tahun yang sama. Novel ini sebelumnya dihadirkan secara berkala dalam mingguan Panorama hampir selama dua bulan mulai 20 April 1927 (Pramono, 2010).

Pada masa reformasi novel Bunga Roos dari Cikembang diterbitkan kembali oleh Marcus A.S dan Pax Benedanto bersama 6 (enam) judul cerita lainnya dalam judul buku Kesastraan Melayu Tionghoa dan Kebangsaan Indonesia Jilid II. Pada terbitan tahun 2001 novel ini menjadi 126 halaman (dari halaman 298 - 425) dan diterbitkan kembali oleh Kepustakaan Populer Gramedia. Novel Bunga Roos dari Cikembang terdiri dari 16 (enam belas) bab yaitu bersubjudul Awan Item yang Mendatengin; Perpisahan; Jau Di Mata, Jau Di Hati; Rahasia Terbenam; Abis Ujan Dateng Panas; Alamat dari Kesedihan; Folie Circulaire; Puhun Puring Mangkok-Mas; Bunga Roos dari Cikembang; Satu Resia dari Dalam Kubur; Lily Idup Kembali; Patung Idup; Kembang Cente dan Harendong; Keheranannya Kota Betawi; dan Bingkisan dari Marsiti.

\section{Sinopsis Novel Bunga Roos dari Cikembang}

Novel ini menceritakan seorang pemuda romantis, Oh Ay Tjeng. Dia seorang adminsitrateur dari Rubber onderneming "Gunung Mulia” yang terletak antara gunung Salak dan gunung Gede. Ay Tjeng sebagai laki-laki yang berhasil dalam karir, hidup di tanah onderneming ditemani seorang wanita pribumi, yang biasa dikenal sebagai nyai. Nyai tersebut bernama Marsiti. Kebersamaan Ay Tjeng dengan Marsiti selama 3 tahun menhadirkan benih cinta sebagai pria dan Wanita, bukan hanya sebagai gundik dan tuannya. Oh Ay Tjeng menolak keras saat sang ayah, Oud Kapitein Oh Pin Lo, mau menikhkan dirinya dengan puteri milyuner Liok Keng Djim yang juga sebagai pemilik "Gunung Mulia", bernama Liok Gwat Nio. Akhirnya berkat beragam upaya sang Kapiten Marsiti dipaksa pergi dari hidup Ah Tjeng sehingga pemuda itu mau menikahi Gwat Nio.

Istri Ah Tjeng, Gwat Nio adalah seorang wanita yang baik. Wanita itu dengan tulus mengabdi dengan sepenuh hati sebagai seorang istri. Gwat Nio tidak pernah mempersoalkan suaminya yang masih sering mengigau menyebut-nyebut nama gundiknya, Marsiti. Justeru hal ini mendorongnya untuk tampil lebih halus, lebih romantic, untuk merebut hati suaminya tersebut. Usahanya berhasil, Oh Ay Tjeng melupakan sang gundik yang terlah pergi, Marsiti, apalagi setelah buah hati mereka lahir dan diberi nama Lily Oh Hoey Eng. 
Sang putri, Lily menjadi seorang gadis yang pandai menyanyi dan bermain piano. Tingkah lakunya sopan dan santun serta amat menyayangi orang tuanya. Ia juga seorang gadis yang tabah, karena saat diramal berumur pendek, dia bahkan selalu berdoa agar orang tuanya memiliki keturunan lagi. Kelembutan, dedikasi, dan kebaikan sang gadis mendorongt orang taunya dan calon mertuanya, Sim Tjoan Hoe, berusaha keras menghindari ramalan itu dengan beragam usaha. Ternyata sebelum pernikahan antara Sim Bian Koen dan Lily terjadi, Lily meninggal dunia.

Bian Koen patah hatinya selama setahun penuh ia terus menengok kuburan Lily. Kekhawatiran orang tua, menutut Bian Koen harus menikah dengan gadis lain. Hanya Bian Koen menolak dengan halus dan meminta ijin akan meneruskan studinya di Tiongkok. Sebelum berangkat dia menyempatkan diri berziarah ke makam Lily. Dia terkejut karena seakan melihat Lily berdiri di tepi kuburan dalam sosok yang nyata. Bian Koen berjuang untuk menemukan sosok tersebut. Atas pertolongan seorang dukun kampung, foto Lily ternyata berwajah sama dengan Roosminah, gadis tercantik di Cikembang, kampung di makam Lily berada.

Ayah Bian Koen menelusuri kehidupan Rossminah yang dimulai darikakek yang hidup bersama Roosminah. Akhirnya ditemukan ibu gadis itu bernama Marsiti yang sudah meninggal, Adapun nama ayah sang gadis bernama Oh Ay Tjeng. Oleh ayah Bian Koen Roos dipertemukan dengan keluarga Ay Tjeng. Keluarga itu dengan gembira dapat menerima kehadiran Roos sebagai pengganti Lily. Penerimaan tersebut tidak hanya disebabkan Roosminah secara fiik mirip dengan Lily, tetapi lebih disebabkan Gwat Nio sebagai istri sah Oh Ay Tjeng sangat menghormati sosok Marsiti sebagai wanita terhormat.

Ah Tjeng dan Gwat Nio kembali ke onderneming "Gunung Mulia" untuk menikmati masa tuanya. Di sana mereka menikmati pohon cempaka yang pernah ditanam Marsiti. Bunga yang beraroma wangi itu seakan dipersembahkan Marsiti kepada suami istri itu sebagai bukti cinta tulus sang gundik kepada juragannya.

\section{Wanita "Nyaie" dalam Novel Bunga Roos dari Cikembang Karya Kwee Tek Hoay}

Istilah bunga roos (mawar) dari Cikembang merupakan simbol yang dipredikatkan kepada seorang wanita cantik dari Cikembang yang bernama Roosminah. Novel tersebut menempatkan tokoh lain sebagai tokoh utama, yaitu ibu dari Roosminah yang bernama Marsiti. 
Sebagai gundik tugas utama Marsiti adalah melayani tuannya, Oh Ay Tjeng dalam pemenuhan kebutuhan fisik, termasuk biologis, selama dia tinggal sebagai pegawai di onderneming "Gunung Mulia" di daerah Bogor. Berdasarkan pemahaman tersebut kajian ini lebih diorientasikan kepada tokoh wanita, Marsiti.

\section{Wanita "nyaie" yang Pasrah}

Catatan sejarah tentang nyai dan pergundikan di era Hindia Belanda menyatakan bahwa saat laki-laki Eropa menunggu calon isteri Eropa yang sesuai dengan kriterianya, laki-laki Eropa “memuaskan diri” bersama perempun Pribumi muda (Baay, 2017: 1). Konsep nyai atau pergundikan kemudian tampaknya diwarisi oleh kelompok Tionghoa, seperti yang dikemukakan oleh Sungkowati (2009) bahwa masyakarat Tionghoa juga akrab dengan konsep nyai dan pergundikan. Menilik kembali tekait politik identitas yang telah dipaparkan oleh Suryani \& Azmy (2016) bahwa masyarakat Tionghoa lebih unggul daripada masyarakat pribumi. Melihat hal itu nyai atau gundik yang diwakili oleh tokoh Marsiti merupakan golongan masyarakat rendah karena Marsiti adalah seorang pribumi. Adapaun Jaelani (2020) mengatakan wanita pribumi dianggap memiliki moral yang rendah. Nyai atau gundik merupakan wanita yang lebih rendah dari perempuan yang lain karena posisinya tidak memiliki ikatan resmi dalam perkwaninan. Oleh karena itu nyai atau gundik tidak dapat menuntut hak yang sama dengan wanita yang dalam ikatan resmi perkawinan. Hal ini semakin menunjukkan bahwa Marsiti selaku tokoh wanita dalam novel Bunga Roos dari Cikembang berada pada posisi paling lemah karena sebagai wanita pribumi dan berstatus sebagai nyai (gundik). Dalam ketidakberdayaan tersebut selaku orang pribumi hanya pasrah dan merendah pada kondisi yang dihadapinya.

Marsiti menjadi seorang "nyaie" dari seorang administrateur onderneming (perkebuman) di daerah Bogor yang brnama Oh Ay Tjeng. Ay Tjeng adalah seorang pemuda keturunan Tionghoa yang berumur 30 tahun dan belum mau menikah dengan seorang istri yang sah (Hoay, 2001: 302). Tugas Marsiti adalah memenuhi kebutuhan fisik tuannya, seperti memasak, mencuci, membersihkan rumah, menemani jalan-jalan di perkebunan (Hoay, 2001 : 306) dan tentu saja melayani kebutuhan biologis (Hoay, 2001). Perannya sebagai nyaie di onderneming karena mengikuti kehendak Oesman, yang sebenarnya bernama Tirta, pembantu tua keluarga Oh Ay Tjeng, yang membawanya pergi dari onderneming 'Gunung Mulia" ke 


\begin{tabular}{l} 
UADESIS \\
Universitas \\
Ahmad Dahlan \\
VOL. No. 1, Januari 2022 \\
\hline
\end{tabular}

daerah Cikembang. Tirta adalah laki-laki tua yang dianggap Marsiti sebagai bapaknya sendiri (Hoay, 2001: 379).

Semua tugas itu diterimanya dengan senang hati sebagaimana ujarannya, " Taiada ada satu apa dalem dunia yang bisa membikin saya susah, sabagitu lama jurgan masih taro cinta dan suka trima pekerjaan saya" (Hoay, 2001:307). Dalam kegelimangan harta dan kasih sayang tuannya, Marsiti masih tetap mampu membawa diri, ia masih tetap memanggil Oh Ay Tjeng dengan sebutan 'juragan' dan menyebut dirinya 'abdi' (saya, budak). Marsiti sering diperlakukan tuannya sebagai pendamping (Hoay, 2001: 306,316). Kepasrahan sebagai "abdi” lebih terlihat nyata pada saat Marsiti justeru menasihati tuannya untuk mau dinikahkan dengan anak milyuner Liok Keng Djim (pemilik onderneming tempat tuannya bekerja) oleh ayahnyan Oud Kapitein Oh Pin Lo. Dengan tabah Marsiti menasihati tuannya.

Marsiti dengan suara gemeter berkata; "Saya rasa juragan mesti turut keinginannya orang tua, sebab anak yang tida menurut pada orang tua, jadi berdosakepada Allah, dan saya pun jadi turut berdosa kalu musti halangin juragan Sepuh punya kehendak...." Marsiti lepasken diri dari pelokan, berjalan ka pintu, sambil menanya pada Pin Ho, "Kapan juragan rasa saya musti berlalu?" (Hoay, 2001: 315)

Oh Pin Lo menganggap Marsiti sebagai bungaraja (gundik/pelacur) yang bersikap materialistis, tukang menjebak, dan tidak setia (Hoay, 2001: 312-313). Namun setelah memperoleh penentangan dari putranya sendiri Oh Ay Tjeng dan laki-laki tua mantan polisi itu membuktikan sendiri ketangguhan dan kepasrahan wanita pribumi tersebut, akhirnya Pin Lo menawarkan jaminan kepada Marsiti jika dia bersedia pergi meninggalkan putranya.

"Saya sedia aken balik ke kampung, dari hal juragan punya kasian dan uwang blanja, dikasih baek, tida pun sudah, sebab saya bisa cari sendiri dengen berkuli."

"Tidak Marsiti," saut Pin Lo, "Aku tanggung yang kau punya juragan nanti kasih tetep blanja saban bulan, bliken rumah, sawah-sawah dan prabotannya supaya kau idup seneng selama-lamanya....(Hoay, 2001: 315)

Pada gambaran di atas terlihat Marsiti menempatkan dirinya sebagai wanita secara biologis, sebagai gundik, makluk yang lemah secara biologis, sebagai pemuas kebutuhan fisik lelaki. Dari gambaran tersebut, baik Oh Pin Lo, Oh Ayn Tjeng dan Marsiti, memiliki pemikiran yang sama dalam kosep nature yaitu wanita diposisikan sebagai makhluk yang lemah yang itu sudah melekat pada diri wanita.

\section{Wanita Tidak Terpelajar yang Cerdas}




\begin{tabular}{l} 
UADESIS \\
Universitas \\
Ahmad Dahlan \\
VOL. No. 1, Januari 2022 \\
\hline
\end{tabular}

Sebagai seorang keturunan pribumi Sunda Marsiti tidak pernah mengenal dunia pendidikan. Dirinya mau menjadi gundik di onderneming pun sekedar agar bisa hidup, bisa makan dan minum layak. Namun demikian dia memiliki kecerdasan yang baik. Hal itu terungkap pada kutipan yang ditulis langsung oleg pengarang secara deskriptif. Dan meskipun Marsiti ada satu perempuan Sunda pagunungan yang tidak terpelajar, tetapi otaknya ada terang hingga dalam tempo sebentar saja Ay Tjeng sudah bisa ajar padanya menulis dan membaca bahasa Melayu dan Sunda dengan huruf Olanda (Hoay, 2001: 315). Pengakuan bahwa Marsiti sebagai wanita cerdas diakui pula oleh Oh Pin Lo. Ayah Ah Tjeng tersebut Marsiti tentu tidak akan mudah keluar dari rumah anaknya. Maka, dia membujuk dengan beragam jaminan dan kekayaan (Hoay, 2001:315). Pada gambaran tersebut terlihat Marsiti telah diposisikan sebagai wanita dalam konsepsi nurture oleh Oh Ay Tjeng dan Oh Pin Lo. Pemaparan tersebut memperlihatkan bahwa wanita yang pintar dibentuk dari kontruksi sosial. Ada pola pengajaran yang diberikan kepada wanita agar dia menjadi lebih pintar.

\section{Wanita Penghibur yang Halus Budi}

Sebagai "nyaie" Marsiti memiliki suara yang merdu dalam menyanyikan lagu-lagu daerah Sunda (Hoay, 2001: 305). Di samping itu Marsiti juga sering diposisikan sebagai pendamping dan teman hidup yang dapat diajak bercengkerama dan tempat mencurahkan perasaan tentang segala hal yang menjadi persoalan Oh Ay Tjeng (Hoay, 2001: 306 - 307).

Kehalusan budi, ketulusan, dan kesetiaan Marsiti terhadap tuannya menempatkan dirinya menjadi wanita yang memiliki konsepsi nurture. Marsiti menempatkan diri sebagai wanita terhormat yang layak diperhatikan, disayangi, dan juga diperhitungkan sebagai makhluk ang juga memiliki pengharapan, walaupun tanpa disadarinya.

\section{Wanita "Nyai" yang dicintai Tuannya}

Walau berperan sebagai "nyaie" Marsiti sendiri tidak merasa dirinya diperlakukan sebagai gundik oleh Oh Ay Tjeng. Hidup bersama di onderneming selama tiga tahun telah membuat dirinya merupakan bagian yang tidak terpisahkan dari tuannya, bahkan ia amat mencintai tuannya tersebut dengan tulus hati (Hoay, 2001: 305). Rasa cinta Marsiti juga dirasakan Oh Ay Tjeng. Maka, Oh Ay Tjeng terus menolak keinginan orang tuanya untuk menikah dengan gadis lain sebagai istri. Rasa saling cinta antar tuan dan gundik tersebut tergambar dalam nukilan berikut. 
"Ach aku kepengen sekali satu waktu bisa pergi jalan-jalan ka itu gunung, akan naek ka puncaknya....Apakah kau suka dan brani turut aken pergi ke sana, Marsiti ?"

"Saya suka turut di mana saja juragan suka ajak."

"Sabagitu lama juragan masih suka piara pada saya, saya tida nanti berlalu dari sini,keculai buat masuk ka lobang kubur." (Hoay, 2001: 306 - 307).

Tokoh Marsiti, sebagai gundik sangat menghormati dan mencintai tuannya. Walaupun wanita pribumi itu tahu, jika ia mengemukakan semua keinginan dan permintaan maka akan dipenuhi tuannya, Oh Ay Tjeng, tetapi dia bukan wanita oportunis. Marsiti tetap rajin, hemat, terawat, baik hati, dan halus budi serta tahu diri posisinya sebagai gundik (Hoay, 2001: 304 - 305). Oh Ay Tjeng adalah tuan dari Marsiti, pemuda Tionghoa ini mencintai nyaie tersebut dengan sepenuh hati. Tinggal bersama selama tiga tahun telah cukup memberi gambaran kepadanya akan kualitas kepribadian gundiknya. Maka, ketika ayahnya mencaci Marsiti, ia pun membelanya dengan berani.

"Papa kliru kalu sangka Marsiti ada satu bungaraja," sahut Ay Tjeng dengen suara perlahan, "Owe ambil nyai padanya waktu ia masih prawan, dan sampe sekarang blon perna unjuk satu kalakuan yang musti dicela, dan bloon perna minta apa-apa yang menjadikan owe punya keberatan, kerna ia punya tabeat ada himat,menurut, dan denger kata..." (Hoay, 2001: 313)

Dari pemaparan di atas terlihat Oh Ay Tjeng tidak saja menempatkan Marsiti sebagai nyai atau gundik yang sekedar memenuhi kebutuhan fisiknya. Tokoh tersebut menempatkan Marsiti sebagai wanita yang utuh, yang layak diperhatikan dan memperhatikan, layak dicintai dan mencintai. Dalam konsepsi gender Richard A Lippa, menempatkan dua konsepsi sekaligus nature sekaligus nurture.

\section{Wanita "Nyai" yang Dihormati Istri Tuannya}

Gwat Nio adalah wanita tionghoa yang menjadi istri sah dari Oh Ay Tjeng. Gadis itu berusaha ingin merebut hati suaminya dari Marsiti yang sudah tiada. Wanita kaya itu mengagumi Marsiti disebabkan ketulusannya, kecantikannya, kesederhanaannya, kehalusan budinya dan rasa hormat kepada suaminya. Sebenarnya Gwat Nio tidak mengenal marsiti secara langsung, semua informasi tentang Marsiti diperoleh dari igauan suami saat tidur dan dari bekas koki suaminya Ma Inun. Rasa kagum Gwat Nio terlihat pada penggalan di bawah ini.

"Apakah kau tida merasa gusar sesudahnya menikah aku masih terus cintaken pada Marsiti ?" 
"Tida, sebab dari keterangannya Ma Inun aku dapet tau, Marsiti ada sampe berharga buat aku cintaken, hingga kalu aku sendiri jadi satu lelaki seperti kau, boleh jadi aku punya kelakuan pun begitu juga." (Hoay, 2001:330)

Rasa takjub Gwat Nio masih ditunjukkan pada saat mengunjungi kuburan Marsiti, setelah 20 tahun menikah dengan Oh Ay Tjeng. Sikap hormat itu ditampilkan dengan melontarkan sebutan "enci (kakak)" kepada kuburan Marsiti (Hoay, 2001:400). Gwat Nio juga memercayai cerita Uwa Kotok yang mengatakan bahwa gambar Marsiti yang sedang dilihat itu diliputi cahaya terang (Hoay, 2001: 414). Dalam hal itu, dapat dilihat bahwa konsepsi yang terbentuk dalam masyarakat bahwa wanita pribumi lebih rendah daripada wanita Tionghoa sedikit bergeser. Gwat Nio sebagai wanita Tionghoa memiliki menghormati Marsiti sebagai wanita pribumi dengan status nyai (gundik).

\section{Wanita "Nyai" yang Mengangkat Derajat Puterinya}

Kepasarahan dan pengabdian yang dilakukan Marsiti kepada tuannya semasa hidup berdampak pada kehidupan puteri tunggalnya, Roosminah. Roosminah dapat dicintai seorang lelaki terhormat tidak lagi harus melalui jalan sebagai "nyaie" seperti ibunya. Namun demikian, sifat dan sikap Roosminah sebagai wanita pribumi tetap dipertahnkan seperti rasa malu dan santun. Gambaran ini terlihat saat Roosminah memberontak dan berlari ketika akan dipeluk Si Bian Koen di dekat makam ibunya (Hoay, 2001: 365) merasa risih saat dipeluk erat Bian Koen di depan orang tua pemuda tionghoa itu (Hoay, 2001: 383). Pada akhirnya Roosminah yang memutuskan sendiri dapat menerima Bian Koen sebagai suami yang disayanginya (Hoay, 2001: 422).

Setelah menyaksikan bahwa wajah gadis itu sama dengan wajah putrinya, Lily yang telah meninggal dunia, Gwat Nio jatuh pingsan karena terharu (Hoay, 2001: 393). Ia mengakui Roosminah sebagai anak kandung dengan sepenuh hati. dan ikhlas menikahkannya dengan Si Bian Koen, calon suami dari putrinya yang telah wafat. Gambaran sikap sopan dan langsung mengaku sebagai orang tuanya ditampilkan Roosinah saat pertama kali bertemu Oh Aj Tjeng dan Gwat Nio (Hoay, 2001: 393) Di samping itu Roosminah amat menyayangi dan meghormati keluarga Bian Koen dengan ketulusan hati (Hoay, 2001: 422-424).

Dari deskripsi di atas terlihat Roosminah telah menempatkan diri sekaligus ditempatkan pula oleh tokoh lain sebagai wanita terhormat. Roosminah sejak awal telah berposisi dalam konsepsi nurture, wanita yang tidak lagi diperhitungkan dari sudut kebutuhan biologis namun 
telah pada kebutuhan konstruksi sosial dan budaya. Akan tetapi pada kontruksi sosial yang dibangun terselip bahwa wanita yang direpresentasikan oleh tokoh Roosminah menunjukkan bahwa wanita dijadikan unsur dari keberlangsuangan masyarakat yang tunduk pada dominasi kekuasaan (Suryakusumma, 2012: 141).

\section{KESIMPULAN}

Berdasarkan analisis yang dilakukan oleh peneliti menunjukkan bahwa Marsiti sebagai wanita "nyaie" (gundik) dari seorang Tionghoa berkelas atas tidak hanya ditempatkan sebagai wanita pemuas nafsu biologis dari tuannya karena kecantikannya, keseksiannya dan pelayanannya (secara nature) namun juga diposisikan sebagai wanita dalam konstruksi sosial (secara nurture) yang baik. Marsiti diakui sebagai "pendamping” yang mampu dijadikan sebagai kawan berpikir tentang beragam problematika kehidupan tuan yang didampinginya akibat kelembuatannya, kecerdasannya dan kesetiannya. Pada sisi lain wanita yang direpresentasikan oleh tokoh Marsiti berada pada posisi yang ambivalen karena dalam kontruksi masyarakat status sebagai nyai (gundik) bukanlah status yang terhormat hal ini diperlihatkan terkait tokoh Marsiti yang bersembunyi (menghilang) dari kehidupan keluarga Tionghoa. Adapun penempatan wanita "nyaie" pada Bunga Roos dari Cikembang karya Kwee Tek Hoay terlihat lebih terhormat dari karya sebelumnya.

\section{DAFTAR PUSTAKA}

Baay, R. (2017). Nyai dan Pergundikan di Hindia Belanda. Komunitas Bambu.

Fakih, M. (2012). Analisis Gender dan Transformasi Sosial. Pustaka Pelajar.

Faruk. (2012). Metode Penelitian Sastra: Sebuah Penjelajahan Awal. Pustaka Pelajar.

Hoay, K. T. (2001). Bunga Roos dari Cikembang (1927). In Kesastraan Melayu Tionghoa dan kebangsaan Indonesia Jilid 2. Kepustakaan Populer Gramedia.

Hudaa, S., Bahtiar, A., Haryanti, N. D., \& Firdaus, W. (2021). Representasi Budaya dalam Novel Boenga Roos dari Tjikembang. Jentera, 10(1), 45-56.

Irenewaty, T., \& Adhi, W. P. (2016). Eksistensi Perjuangan Wanita Masa Kolonial. Istoria, $11(2), 13-27$.

Jaelani, G. A. (2020). Perempuan Sunda dan Pelacuran di Zaman Kolonial. Purbawidya, 9(2), 199-216.

Lippa, R. A. (2005). Gender, Nature, and Nurture. Lawrence Erlbaum Associates.

Meij, L. S. (2009). Ruang Sosial Baru Perempuan Tionghoa: Sebuah Kajian Pascakolonial. Yayasan Obor Indonesia.

Nugroho, A., \& Purnomo, D. T. (2017). Citra Perempuan dalam Karya Sastra Peranakan Tionghoa. Buana Gender, 2(2), 165-176.

Pramono, D. (2010). Menelaah Pola Interaksi dalam Sastra Melayu Tionghoa. Forum Sastra Lamongan (FSL). https://forum-sastra-lamongan.blogspot.com/search?q=bunga + roos ${ }^{+}$ 


\begin{tabular}{lc}
\hline MIMESIS & MIM \\
Universitas & VOL. 3. No. 1, Januari 2022 \\
Ahmad Dahlan & \\
\hline
\end{tabular}

Pramono, D. (2019). Citra Wanita Pribumi dalam Sastra Melayu Tionghoa. Sesanti (Seminar Bahasa, Sastra, Dan Seni), 348-363.

Sungkowati, Y. (2009). Hubungan Etnis Jawa dan Tionghoa dalam Novel Tunggak-Tunggak Jati. Diksi, 16(1), 55-66.

Suryakusumma, J. (2012). Agama. Seks, dan Kekuasaan. Komunitas Bambu.

Suryani, \& Azmy, A. S. (2016). Politik Identitas dan Nasionalisme Kebangsaan (Studi Atas Penguatan Politik Identitas Etnis Tionghoa di Indonesia Pasca Orde Baru). 